\title{
Potential of Launea taraxacifolia (Willd) Amin Ex. C. Jeffrey for in Vitro Regeneration
}

\author{
Ayobola M. SAKPERE, Ejeoghene R. AYISIRE, Olufemi I. ABIOYE \\ Obafemi Awolowo University, Department of Botany, Ile-Ife, Nigeria; aasakpere@oauife.edu.ng
}

\begin{abstract}
This study investigated the potential of Launea taraxacifolia for in vitro regeneration. Stem and leaf explants were inoculated on full strength Murashige and Skoog (MS) medium supplemented with varying concentrations of 2, 4-dichlorophenoxyacetic acid (2,4-D). Leaf explants responded to all concentrations of 2,4-D used while stem explants responded to only two of the 2, 4-D concentrations suggesting that leaf explants might be a better source of explants. Leaf explants generated shoots on medium supplemented with $0.5 \mathrm{mg} / \mathrm{l}$ kinetin and $0.1 \mathrm{mg} / 12$, 4-D. This study is the first report on in vitro regeneration of Launea taraxacifolia.
\end{abstract}

Keywords: 2,4-D, "Efo yanrin", kinetin, micropropagation, vegetable, wild lettuce

\section{Introduction}

Launea taraxacifolia (Willd) Amin., Ex. C. Jeffrey also known as wild lettuce, is an erect rhizomatous annual or perennial herb with greyish blue bloom (Akobundu and Agyakwa, 1998). It was formerly referred to as Lactuca taraxacifolia Ex. Hornemann and is known as "Efo yanrin" by the Yoruba people of Southern Nigeria. It is generally collected from the wild in Nigeria and other parts of Afri$\mathrm{ca}$, and has been suggested to originate from the Ethiopian highlands from where it spreads as weed to other parts of the world.

Adegbite (1987) reported that it is used as common vegetables by the African people; the leaves can be eaten fresh as a salad or cooked in soups and sauces. The leaves are fed to nursing cattle particularly in northern Nigeria where it is claimed to increase milk production and induce multiple births (Burkill, 1985). Medicinally, the leaves, when rubbed on limbs have been reported to enhance walking in children, the Yoruba people of southern Nigeria mix the leaves of $L$. taraxacifolia with local black soap for curing skin diseases. It is also reported to have therapeutic uses for respiratory problems and chest congestion and the milky latex can be used to cure the popular eye disease called conjunctivitis (Adegbite, 1987; Ayensu, 1978; Dalziel, 1948; Schipper, 2000).

L. taraxacifolia is one of the undervalued reservoirs of diversity of African leafy vegetables which are extremely important for food security, nutrition and poverty alleviation throughout the continent. Apart from being displaced in many areas, many local vegetable species that are used have been neglected by science and development (Chwenya and Eyzaguirre, 1999; Opabode and Adebooye, 2005). Adebooye et al. (2003) also reported that most of these African leafy vegetables are not easily available as farmers now gather them with great drudgery and difficulty from the few stands that are left in the wild. 'Yanrin' is one of the traditional leafy vegetables that are important especially in Nigeria. It is known to have low seed viability (Adegbite, 1987) and reproduces asexually by sprouting vigorously from roots. According to Adebisi (2004), selection of plants with tender leaves of low bitterness would increase its popularity .

However, Sakpere and Aremu (2008) reported that, a limitation to cultivation and domestication of this plant is a lack of variability imposed by vegetative mode of propagation. Since the plant is propagated mainly by vegetatively propagation, conventional breeding is inefficient. Molecular breeding will therefore be a more efficient method for genetic improvement of the plant and in vitro propagation methods are essential for molecular breeding.

Variation differences are the basis of plant breeding and in recent times many new techniques have become available for breeders, many of which take advantage of the ability to regenerate whole plants from single cells. In vitro cultured cells can differentiate into whole plants through organogenesis or somatic embryogenesis. Plants regenerated in this way are known to exhibit variation called 'somaclonal variation' (Larkin and Scowcroft, 1981). One of the prerequisites for a successful application of in vitro selection is the presence of in vitro regeneration techniques. However, in vitro propagation protocols for L. taraxacifolia have not been reported even though Opabode and Adebooye (2005) suggested the establishment of an in vitro propagation protocol for the plant. Therefore, a micro propagation study was initiated to test the potential of the plant for in vitro regeneration and to establish benchmarks for the development of protocols for in vitro propagation of the plant. This study, to our knowledge is the first report on the in vitro propagation of $L$. taraxacifolia. 
94

\section{Materials and methods}

\section{Plant materials}

Twenty five roots of $L$. taraxacifolia plants growing near the Department of Botany, Obafemi Awolowo University, Ile-Ife, Osun State, Nigeria, between latitude: $7^{\circ} 467^{\prime} \mathrm{N}$, longitude: $4^{\circ} 567^{\circ} \mathrm{E}$ were collected and buried in six plastic pots filled with top soil. Holes of about $1-2 \mathrm{~cm}$ diameter were bored at the base of the pots in order to facilitate drainage. The pots were left outside under ambient conditions and watered daily in order to ensure good establishment and rapid sprouting of plants. The plants generated from these roots were used as source of explants.

Explants collected from healthy $L$. taraxacifolia plants raised as above were washed under running tap water to remove dirt and reduce microbial population. The explants were then sterilized with a solution of $5 \%(\mathrm{v} / \mathrm{v})$ sodium hypochlorite $(\mathrm{NaOCl})$ and two drops of 'Tween 20' for 10 minutes. The explants were rinsed in three changes of sterile distilled water. The leaves were then wounded by trimming their edges and then cutting them into about $2 \mathrm{~cm}^{2}$ pieces. Stem explants were cut into $1 \mathrm{~cm}$ long pieces. The stem and leaf explants were cultured separately. All protocols were carried out under the laminar airflow chamber. Each experimental unit was repeated five times.

Full strength Murashige and Skoog (MS) medium (Murashige and Skoog, 1962) supplemented with varying concentrations of 2, 4-dichlorophenoxyacetic acid (2, 4-D) $(0.1,0.4$ and $0.8 \mathrm{mg} / \mathrm{l})$ and Kinetin $(\mathrm{K})(0.5$ or 1.0 $\mathrm{mg} / \mathrm{l})$ was used in all experiments. The $\mathrm{pH}$ of the media was adjusted to $5.7 \pm 0.1$ and gelled with $0.8 \mathrm{~g}$ agar prior to autoclaving at $121^{\circ} \mathrm{C}$ and $108 \mathrm{KPa}$ (15 psi) pressure for 15 minutes. The cultures were incubated in the dark at $25^{\circ} \mathrm{C} \pm 2^{\circ} \mathrm{C}$. MS medium without growth regulators served as the control. The explants were evaluated visually for the presence and type of callus and then scored (Remotti and Loffler, 1995). Results were observed at regular intervals and data collected were presented as percentages.

\section{Results and discussion}

Leaf explants on MS medium without plant growth regulators (PGR) produced callus within 2 weeks, some developed roots in addition, but no shoot. This could be as a result of high level of endogenous PGR's, particularly auxins, in the leaf explants. It has been reported that callus formation can be correlated with high endogenous auxin concentration in leaves and might have a potential for triggering induction of somatic embryogenesis (Mashayekhi et al., 2008; Welander and Snygg, 1987). Using cold treated capitula explants, Sands et al. (2003) reported that PGRfree MS was the better medium for shooting compared to all other treatments in the micropropagation of Calocephalus lacteus. Callus was not formed on stem explants inoculated on PGR free MS medium.

Roots were generated on leaf explants in cultures containing MS media supplemented with $0.1 \mathrm{mg} / 12,4-\mathrm{D}$ in 1 week and in cultures supplemented with $0.4 \mathrm{mg} / 12,4-\mathrm{D}$ in 5 weeks. However, in cultures containing MS medium supplemented with $0.8 \mathrm{mg} / \mathrm{l} 2,4-\mathrm{D}$, cream coloured callus was produced on leaf explants after 7 weeks. This may suggest inhibition of organogenesis at concentrations above $0.4 \mathrm{mg} / 12$, 4-D.

For stem explants, root formation was initiated after $61 / 2$ weeks on MS medium supplemented with $0.1 \mathrm{mg} / \mathrm{l} 2,4-\mathrm{D}$ only; callus was initiated on stem explants inoculated on medium supplemented with $0.4 \mathrm{mg} / 1$ 2,4-D, while stem explants cultured on MS medium supplemented with 0.8 $\mathrm{mg} / 1$ 2,4-D showed no response. The highest percentage response was obtained from leaf explants (Tab. 1 and Fig. 1) suggesting that leaf explants are a better choice for micropropagation of L. taraxacifolia.

The choice of explants is of cardinal importance and makes an absolute difference between success and failure in inducing regeneration in vitro. This is because different explants and even callus do not respond in the same way to different growth regulators. Callus initiated on different explants showed varying textures and colour (Tab. 2).

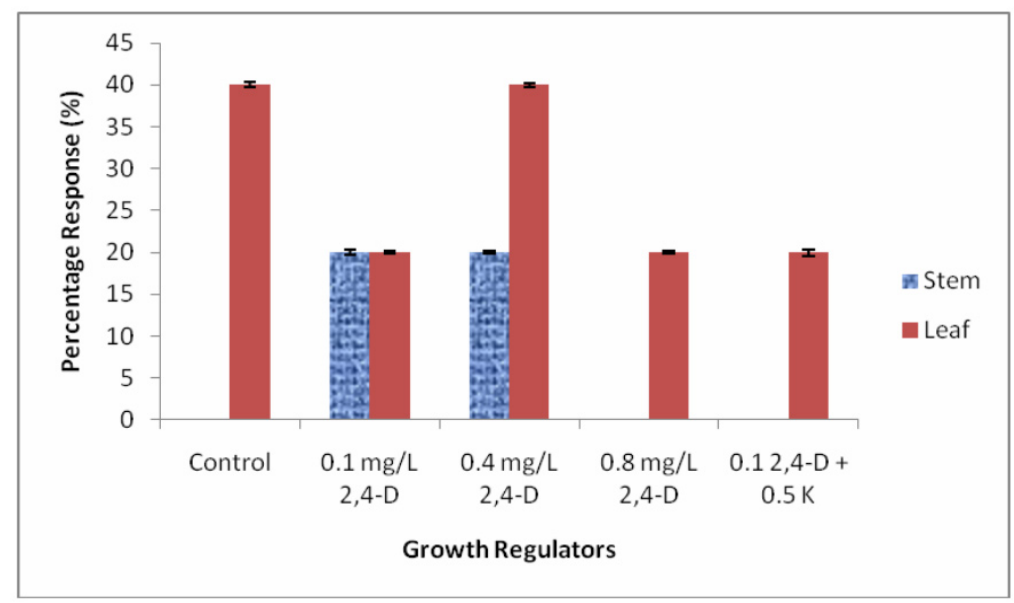

Fig. 1. Response of Launea taraxacifolia explants to MS medium supplemented with 2,4-D alone or in combination with Kinetin 
Tab. 1. Types of responses induced on stem and leaf explants of Launea taraxacifolia grown on MS medium supplemented with 2,4-D alone or in combination with Kinetin

\begin{tabular}{cccccccc}
\hline \multirow{2}{*}{ Explant } & \multirow{2}{*}{$\begin{array}{c}\text { Total Response } \\
\text { from explants (\%) }\end{array}$} & \multicolumn{5}{c}{ Type of Response (\%) } \\
\cline { 3 - 7 } & 10 & $\mathrm{C}$ & $\mathrm{C} / \mathrm{R}$ & $\mathrm{R}$ & $\mathrm{R} / \mathrm{S}$ & $\mathrm{C} / \mathrm{R} / \mathrm{S}$ \\
\hline Stem & 28 & 5 & 5 & - & - & - \\
Leaf & & 8 & 4 & 12 & - & 4 \\
\hline
\end{tabular}

Key: C = Callus only; C/R = Callus/Root; $\mathrm{R}=$ Root only; $\mathrm{R} / \mathrm{S}=$ Root $/$ Shoot; $\mathrm{C} / \mathrm{R} / \mathrm{S}=$ Callus $/$ Root $/$ Shoot

Leaf explants that had generated roots on medium supplemented with $0.1 \mathrm{mg} / \mathrm{l}$ 2,4-D sub-cultured unto a medium supplemented with $0.1 \mathrm{mg} / \mathrm{l} 2,4-\mathrm{D}$ and $1.0 \mathrm{mg} / \mathrm{l}$ Kinetin generated callus while leaf explants inoculated on medium supplemented with $0.5 \mathrm{mg} / \mathrm{l} \mathrm{Kinetin} \mathrm{and} 0.1 \mathrm{mg} / \mathrm{l}$ 2,4-D, generated compact, dark brown callus after which shoots emerged from the explant followed by more roots (Plate 1B). According to Stojakowska and Malarz (2004), the tendency to indirect organogenesis was diminished when Kinetin was used in cultures.

However, in the in vitro propagation of Vernonia amygdalina, Khalafalla et al. (2007) reported that Benzyl adenine (BA) alone or in combination with Naphthalene acetic acid (NAA) was more effective for shoot multiplication than Kinetin alone or in combination with 2,4-D, mainly because explants grown on the medium containing Kinetin alone or in combination with 2,4-D formed excessive callus and callus growth on explant have been reported to interfere with the propagation process (Thiem, 2003).

In the tissue culture of Lactuca sativa, Pink and Carter (1987) reported that medium supplemented with 0.5 $\mathrm{mg} / \mathrm{l} \mathrm{Kinetin} \mathrm{gave} \mathrm{poor} \mathrm{shoot} \mathrm{growth} \mathrm{while} 1.0 \mathrm{mg} / \mathrm{l} \mathrm{Ki}$ netin promoted shoot growth. However, in the present study, addition of $0.5 \mathrm{mg} / \mathrm{l}$ Kinetin to the culture medium promoted shoot development while the addition of 1.0 $\mathrm{mg} / \mathrm{l}$ Kinetin promoted callus formation. There have been reported differences in tissue sensitivity to plant growth regulators (Lisowska and Wysokinska, 2000). Depending on the ultimate aim of the experiment, different plant growth regulators are employed.

Media containing Benzyl adenine (BA) together with NAA have been reported to be preferably used for multiple shoot induction and maintenance in Asteraceae plants (Stojakowska and Malarz, 2004). According to Trejgell et
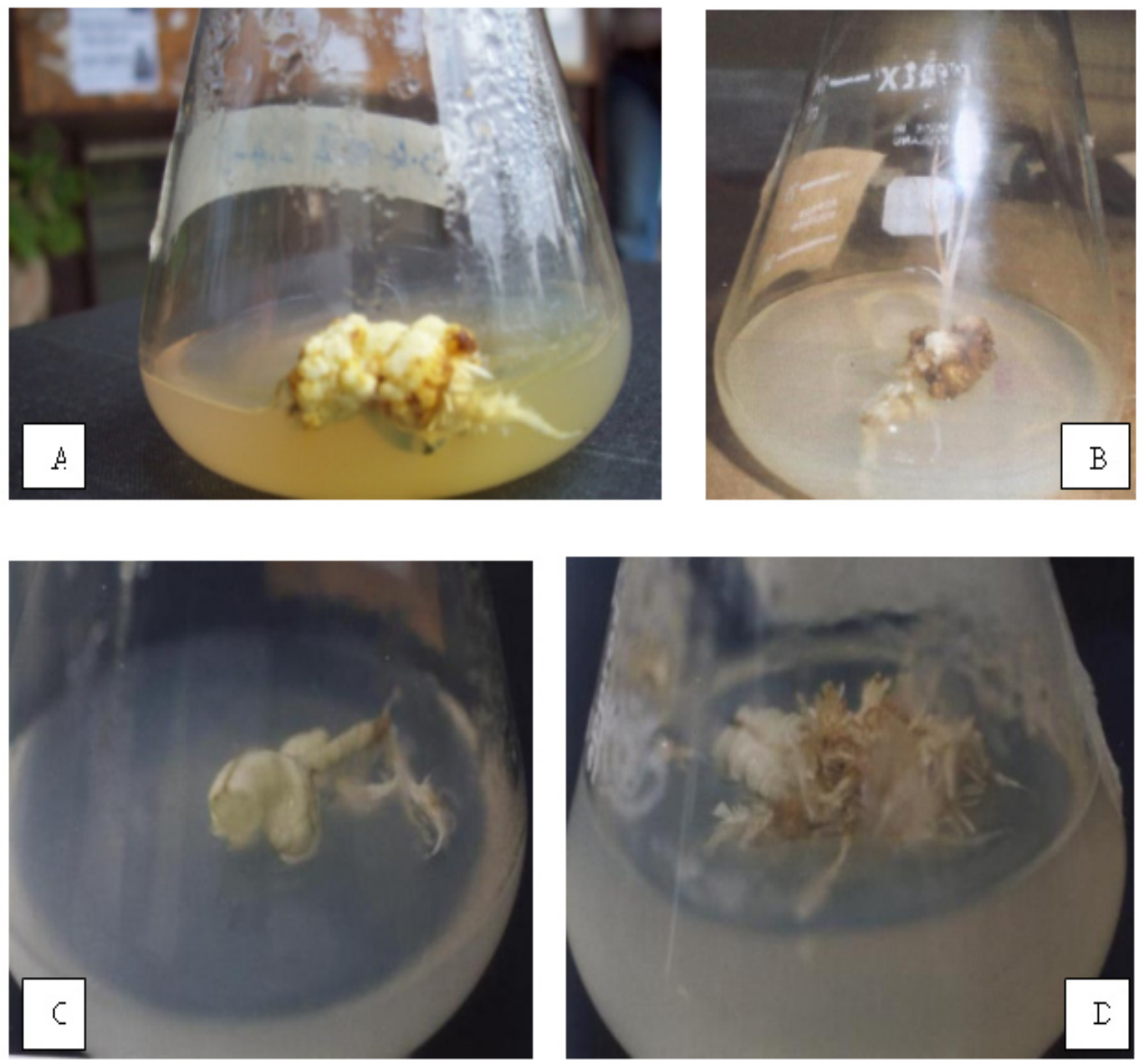

Plate 1. Responses of L. taraxacifolia leaf explants to MS medium supplemented with 2,4-D alone or in combination with Kinetin: A: leaf inoculated on MS+ 0.4mg/12, 4-D showing roots; B: Plantlet generated on leaf explants inoculated on MS+ $0.5 \mathrm{mg} \mathrm{l}^{-1} \mathrm{kinetin}$ and $0.1 \mathrm{mg} \mathrm{l}^{-1}$ 2,4-D; C: Roots on leaf explants inoculated on MS+ 0.1 mg/12, 4-D and D: Roots on leaf explants inoculated on MS medium without growth regulators 
Tab. 2. Effect of MS medium supplemented with 2,4-D alone or in combination with Kinetin on type of callus induced on Launea taraxacifolia explants

\begin{tabular}{cccccc}
\hline & Explant & Callus size $(\mathrm{Cms})$ & Colour & Texture & Induction time (weeks) \\
\hline Control & Leaf & $\leq 1$ & Beige & Soft friable & 2 \\
$0.1 \mathrm{mg} / \mathrm{l} 2,4-\mathrm{D}$ & Stem & $\leq 1$ & Cream & Pulpy & 2.5 \\
$0.4 \mathrm{mg} / \mathrm{l} 2,4-\mathrm{D}$ & Stem & $\leq 1$ & Off white & Loose & 5 \\
$0.8 \mathrm{mg} / \mathrm{l} 2,4-\mathrm{D}$ & Leaf & $\leq 1$ & Cream & Pulpy & 7 \\
$0.1 \mathrm{mg} / 12,4-\mathrm{D}+0.5 \mathrm{mg} / \mathrm{l} \mathrm{K}$ & Leaf & $\leq 1$ & Dark Brown & Compact & 5 \\
\hline
\end{tabular}

al. (2009), the caulogenic role of BA has been shown in other plants of the Asteraceae family.

This needs to be tested for Launea taraxacifolia since it is known that different species can respond differently to the same growth regulators. The effect of higher concentrations of Kinetin also needs to be investigated.

\section{Conclusions}

In conclusion, this study has established the potential for in vitro regeneration of Launea taraxacifolia. Further research in order to develop an efficient micropropagation system for the species and to compare the effects of BA and NAA and 2, 4-D and kinetin is ongoing.

\section{References}

Adebisi AA (2004). Launaea taraxacifolia (Willd.) Amin ex C. Jeffrey. In: Grubben GJH, Denton OA (Ed.). PROTA 2: Vegetables/Légumes. PROTA, Wageningen, Netherlands.

Adebooye OC, Ogbe FMD, Bamidele JF (2003). Ethnobotany of indigenous leaf vegetables of South West Nigeria. Delpinoa 45:295-299.

Adegbite AE (1987). Biosystematics studies of some species of the tribe Cichorieae (Asteraceae) in Nigeria. Unpublished M. Sc. Thesis. Department of Botany, O.A.U., Ile-Ife, Nigeria.

Akobundu IO, Agyakwa CW (1998). Ref: A Handbook of West African Weeds ( $2^{\text {nd }} E d$.). Produced by International Institute of Tropical Agriculture, IITA.

Ayensu ES (1978). Medicinal Plants of West Africa. Reference Publication, INC, p.104.

Burkill HM (1985). The useful plants of West Tropical Africa. $2^{\text {nd }}$ Edition. Volume 1, Families A-D. Royal Botanic Gardens, Kew, United Kingdom.

Chwenya JA, Eyzaguirre PB (1999). The biodiversity of traditional leaf vegetables. International Plant Genetics Resource Institute, Rome, Italy.

Dalziel JM (1948). The useful plants of West Tropical Africa. Published by the Crown Agents for the Colonies, London.

Khalafalla MM, Elgaali EI, Ahmed MM (2007). In vitro Multiple Shoot Regeneration from Nodal Explants of Vernonia amygdalina-An important medicinal plant. Afr Crop Sci ConfProc 8:747-752

Larkin PJ, Scowcroft WR (1981). Somaclonal variation - a novel source of variability from cell cultures for plant improvement. Theor Appl Genet 60:197-214.
Lisowska K, Wysokinska H (2000). In vitro propagation of Catalpa ovata G. Don. Plant Cell Tissue Organ Cult 60:171-176.

Mashayekhi K, Sharifani M, Shahsavand M, Kalati H (2008). Induction of somatic embryogenesis in absence of exogenous auxin in cucumber (Cucumis sativus L.). Intern J Plant Produc 2(2):163-166

Murashige T, Skoog F (1962) A revised medium for rapid growth and bioassays with tobacco tissue cultures. Physiol Plant 15:473-497.

Opabode JT, Adebooye OC (2005). Application of biotechnology for the improvement of Nigerian indigenous leaf vegetables. Afr J Biotechnol 4(3):138-142.

Pink DAC, Carter PJ (1987). Propagation of lettuce (Lactuca sativa) breeding material by tissue culture. Ann App Biol 110(3):611-616.

Remotti PC, Loffler HJM (1995). Callus Induction and Plant regeneration from Gladiolus. Plant Cell Tissue Organ Cult 42:171-178.

Rita I, Floh EIS (1995). Tissue culture and micropropagation of Cuphea ericoides, a potential source of medium-chain fatty acids. Plant Cell Tissue Organ Cult 40:187-189.

Sakpere AMA, Aremu OA (2008). The growth of Launaea taraxacifolia (Asteraceae) and its response to shading. Res J Bot 3(2):90-96.

Sands RJ, Brown NR, Koutoulis A (2003). Micropropagation of two threatened tasmanian species of Calocephalus (Asteraceae), with comments on phenotypic plasticity. Austr J Bot 51(4):415-420.

Schipper RR (2000). African Indigenous Vegetables. An Overview of the cultivated species. Chatham, U.K: Natural Resource Institute/ACP.EU Technical Centre for Agricultural and Rural Cooperation.

Stojakowska A, Malarz J (2004). In vitro propagation of Inula royleana DC. Acta Soc Bot Poloniae 73(1):5-8.

Thiem B (2003). In vitro propagation of isoflavone producing Pueraria lobata (Willd.) Ohwi. Plant Sci 165:1123-1128.

Trejgell A, Bednarek M, Tretyn A (2009). Micropropagation Of Carlina Acaulis L. Acta Biol Cracov Series Botanica 51(1):97-103.

Welander M, Snygg JO (1987). Effect of Applied and Endogenous Auxin on Callus and Root Formation of in vitro Shoots of the Apple Rootstocks M26 and A2. Ann Bot $59(4): 439-443$ 